\title{
EFFECT OF DIETARY GLUTAMIC ACID ON PRODUCTIVE PERFORMANCE AND CARCASS TRAITS OF GROWING APRI RABBITS
}

\author{
Shabaan, Hoda A.; Amany A. Khayyal; Mervat N. Ghazal and \\ M. A. M. Sheteifa \\ Anim. Prod. Res. Inst., Agric. Res. Center, Ministry of Agric., Dokki, \\ Giza, Egypt
}

\begin{abstract}
This study aimed to find out the effect of supplementing two sources of dietary glutamic acid (artificial and natural) in rabbit diets on productive performance and carcass traits of growing APRI rabbits. The basal diet was formulated to meet nutrients recommendations. A total number of 150 APRI rabbit kids were weaned at five weeks of age with an average body weight of $667.48 \pm 3 \mathrm{~g}$. The rabbits were distributed according to body weight to five equal groups $(G, n=30$ each, from weaning to 16 weeks of age). The five groups were assigned at random to five dietary treatments. The control (G1) was fed ad-libitum on a basal commercial pellet diet; diets of G2 and G3 were supplemented with artificial source of glutamic acid at a rate of 0.125 and $0.25 \%$, respectively. While part of rations of G4 and G5 were substituted with a natural glutamic acid using tomato by-products at a rate of 5 and $10 \%$ (contained natural glutamic acid, 0.125 and $0.25 \%$ ), respectively. At the end of the experimental period (16 weeks of age), digestibility trials were carried out to determine the digestibility of feed nutrients and feeding value of the experimental diets. In addition, four rabbits were slaughtered from each group to study the carcass traits and some blood parameters.

Results showed that body weight tended to be higher in G3 and G5 during the period from 5-12 and 5-16 weeks of age, than that in $\mathrm{G} 1, \mathrm{G} 2$ and $\mathrm{G} 4$, respectively. The highest weight gain values from 5-12 and 5-16 weeks were observed with G3 and G5. Feed intake was significantly affected by the diets. Lowest average feed intake from weaning to slaughter (5-16 weeks of age) was recorded for G4. Better feed conversion and performance index (\%) were for G3 and G5 than in the other groups, in all ages. No significant differences of digestibility coefficients of nutrients among studied groups were observed. The maximum mortality rate was recorded in $\mathrm{G} 1$ and $\mathrm{G} 4$, respectively. The empty carcass (\%) was significantly higher in G5. Dressing \% and carcass cuts were higher for G5. The lowest values of AST and ALT (U/I) were recorded in rabbit of G2 and G3 than the other groups. Rabbits fed diet G3 recorded the lowest values of plasma urea and creatinine $(\mathrm{mg} / \mathrm{dl})$ followed by $\mathrm{G} 4$ and $\mathrm{G} 5$, while the highest value was shown with $\mathrm{G} 1$.

In conclusion, natural source of glutamic acid (tomato by-products) could be valid feed ingredient due to its good content of glutamic acid could be included in rabbit diets in levels up to $10 \%$ for better productive performance, carcass traits, physiological function and economic revenue.
\end{abstract}

Keywords: APRI rabbits, glutamic acid, tomato by-products, productive performance, digestibility, carcass traits, economical efficiency

\section{INTRODUCTION}

Some amino acids in diets could reduce intestinal atrophy submitted to parenteral feeding (Pierzynowski and Sjodin, 1998). Glutamine has been 


\section{Shabaan, Hoda A. et al.}

utilized as an important energy source for the development of the intestinal mucosa, cell proliferation by improving ornithine carboxylase activity (Fischer da Silva, 2001). Research has shown that glutamine and glutamic acid (Newsholme et al., 2003) as well as essential oils and plant extracts (Pelicia et al., 2011) have the ability of improving the immune response and the intestinal microflora thus preventing their negative repercussions on the intestinal structure and improving the absorption of nutrients and animal performance through increasing the absorptive surface of gastrointestinal mucosa and the utilization of dietary nutrients (Fischer da Silva et al., 2007). Glutamine plays an important role in the intestinal health without effects on growth performance (Baylos et al., 2008). Chamorro et al. (2007a \& b) indicated that dietary supplementation with $1 \%$ of glutamine in rabbits diet reduces mortality rate. Moreover, glutamic acid is converted into glucose and helps to maintain the acid/alkaline balance (Christy, 2010). Glutamic acid (glutamate) is one of the 20 amino acids commonly found in proteins and plays a central role in amino acid metabolism. Glutamic acid is converted to glutamine and could be synthesized from several different amino acids, including glutamine, since feeding glutamine leads to an elevation of glutamic acid (Kharchenko, 2012).

Dried tomato pomace (DTP), as a by-product, is a mixture of tomato skin, pulp and crushed seeds that remain after the processing of tomato for juice, paste and/or ketchup (Mirzaei-Aghsaghali et al., 2008 and Ventura et al., 2009). This by product is a good source of amino acids, energy and crude fiber. In addition, it contains more essential amino acids for rabbits feeding as compared to alfalfa meal (King and Zeidler, 2004 and Karadas et al., 2006). Tomato pomace (TP) can be introduced in the growing rabbit's diet without any problem on growth performance (Sindhu et al., 2002). It is a cheap source of energy and nutrients than many alternative ingredients with potential biological value (Devasena et al., 2007). Tomato is one of the major vegetables of world production; the annual production of tomato in Egypt is 8.1 million tones resulting in production of $20.3 \%$ of manufacturing byproducts (FAO, 2011).

Increasing rabbit's meat consumption has been a challenge in the last few years; high prices associated with lack of interest in whole carcasses have contributed to this situation. The development of processed products such as retail cuts and precooked meals is an attempt to meet the changing demand. Knowledge about carcass traits such as weight and percentage of prime retail cuts are essential for this new market (Blanospino et al., 2004), slaughter weight may affect carcass composition and meat quality. Consumers usually buy the whole carcass, but in recent years a market for retail cuts has been developed. Breeds differ in carcass traits and meat quality at the same market weight due to differences in degree of maturity (Piles et al., 2000 and Dalle Zotte, 2002).

The aim of the present study was to evaluate the effect of adding glutamic acid (either artificial or natural) on productive performance, digestibility, carcass traits and some blood parameters of growing APRI rabbits. 


\section{MATERIALS AND METHODS}

The experimental work of the present study was carried out during the period from January to March 2012 (for 11weeks) at Sakha Research Station, Kafer El-Sheikh Governorate, Animal Production Research Institute (APRI), Agriculture Research Center (ARC), Ministry of Agriculture, Dokki, Giza, Egypt and the chemical analysis was carried out at laboratories of APRI, ARC. An ample amount of tomato by-products was provided by Heinz Company, 6 October, Cairo, while glutamic acid was provided by AlGumhoria Company.

Tomato by-products (after manufacturing tomato ketchup) including skin, seeds and hard tissues (TP) were sun-air dried for seven days, then completely ground in a hummer mill before mixing with the other ingredients and stored in bags until use. The samples of the tested material were analyzed for crude protein (CP), crude fiber (CF), ether extract (EE) and ash. Dried tomato by-products were analyzed for fiber fractions, neutral detergent fiber (NDF), acid detergent fiber (ADF) and acid detergent lignin (ADL) using Tecator Fibretic System according to Goering and Van Soest (1970) procedures. Samples were ashed in an oven at $600^{\circ} \mathrm{C}$ for two hours; digested with $\mathrm{HCl} 50 \%$ concentration in boiling water bath and then diluted with water to $100 \mathrm{ml}$ in order to determine calcium and phosphorus by using atomic absorption spectrophotometer. Amino acids concentrations were measured using a Bekman 7300 High Performance Amino Acids Analyzer according to the methods of A.O.A.C. (1996) at the central laboratory for feeds and feeding (CLFF), Agriculture Research Center, Giza, Egypt. The experimental diets were manufactured at Noubaria Research Station, APRI. Composition and calculated chemical analysis of the experimental diets and Chemical analysis and amino acid contents (\%) of tomato by-products (TP) are presented in Tables 1 and 2 .

\section{Experimental design and management:}

A total of 150 of APRI rabbit kids, weaned at 5 weeks with body weight of $667.48 \pm 3 \mathrm{~g}$, were divided according to body weight into five groups (each of 30 kids). All rabbits were vaccinated against common diseases. The rabbit groups were randomly allocated to five treatments are G1 (control), which was fed ad-libitum on a basal commercial pellet diet without any additives. Both G2 and G3 groups were supplemented with an artificial source of glutamic acid at the rate of 0.125 and $0.25 \%$, respectively. While, rations of G4 and G5 were included a natural source of TP (contain natural glutamic acid, 0.125 and $0.25 \%$ ) at the rate of 5 and $10 \%$ from clover hay, respectively (Table 1). The experimental diets were formulated to be iso-nitrogenous $(\sim 17 \%$ $\mathrm{CP}$ ) and iso-caloric ( $2500 \mathrm{Kcal} \mathrm{DE} / \mathrm{Kg}$ diet). All diets were in pellets to satisfy the nutrients requirements of growing rabbits according to Agriculture Ministry Decree (1996). The experimental diets were fed to growing rabbits during the whole experimental period (from weaning till $16^{\text {th }}$ weeks of age). Rabbits were housed individually in galvanized wire batteries $(20 \times 35 \times 40 \mathrm{~cm})$ in a well 
ventilated building $(15 \times 11 \times 4 \mathrm{~m})$ where the air temperature and humidity were at natural limits. Fresh water was available at all the time from automatic drinkers with nipples for each cage. Rabbits were observed daily, kept under the same management hygienic and environmental conditions. All rabbits were vaccinated against common diseases.

Table (1): Composition and calculated analysis of the experimental diets (as fed).

\begin{tabular}{|c|c|c|c|c|c|}
\hline \multirow{2}{*}{ Item } & \multicolumn{5}{|c|}{ Experimental diets } \\
\hline & G1 & G2 & G3 & G4 & G5 \\
\hline \multicolumn{6}{|l|}{ Ingredients (\%): } \\
\hline Clover hay $(12 \% \mathrm{CP})$ & 30.00 & 30.00 & 30.00 & 25.00 & 20.00 \\
\hline Tomato by-products & - & - & - & 5.00 & 10.00 \\
\hline Yellow corn & 20.00 & 20.00 & 20.00 & 21.00 & 23.35 \\
\hline Soybean meal (44\%CP) & 17.55 & 17.54 & 17.60 & 16.05 & 14.95 \\
\hline Wheat bran & 26.20 & 26.09 & 25.90 & 26.65 & 25.35 \\
\hline Molasses & 4.00 & 4.00 & 4.00 & 4.00 & 4.00 \\
\hline DL-Methionine & 0.10 & 0.10 & 0.10 & 0.10 & 0.10 \\
\hline Glutamic acid & - & 0.125 & 0.25 & - & - \\
\hline Vitamins \& minerals mixture $^{1}$ & 0.30 & 0.30 & 0.30 & 0.30 & 0.30 \\
\hline Salt & 0.50 & 0.50 & 0.50 & 0.50 & 0.50 \\
\hline Limestone & 1.05 & 1.05 & 1.05 & 1.30 & 1.45 \\
\hline Di-Calcium phosphate & 0.30 & 0.30 & 0.30 & 0.10 & - \\
\hline Total & 100 & 100 & 100 & 100 & 100 \\
\hline \multicolumn{6}{|l|}{ Calculated analysis ${ }^{2}$ : } \\
\hline Dry matter (DM), \% & 87.20 & 87.10 & 87.00 & 87.40 & 87.60 \\
\hline Crude protein (CP), \% & 17.03 & 17.00 & 17.00 & 17.01 & 17.01 \\
\hline Ether extract (EE), \% & 2.71 & 2.70 & 2.69 & 3.06 & 3.40 \\
\hline Nitrogen free extract (NFE), \% & 47.82 & 47.77 & 47.71 & 47.62 & 47.60 \\
\hline Ash, \% & 6.02 & 6.02 & 6.01 & 5.75 & 5.42 \\
\hline Digestible energy (DE), kcal/kg) ${ }^{3}$ & 2518 & 2514 & 2512 & 2503 & 2501 \\
\hline Crude fiber (CF), \% & 13.62 & 13.61 & 13.59 & 13.99 & 14.22 \\
\hline NDF, $\%$ & 37.87 & 37.87 & 37.85 & 38.12 & 38.27 \\
\hline ADF, \% & 21.85 & 21.84 & 21.83 & 22.19 & 22.40 \\
\hline Hemicellulose, \% & 16.02 & 16.03 & 16.02 & 15.93 & 15.87 \\
\hline Calcium, \% & 1.01 & 1.01 & 1.01 & 1.02 & 1.01 \\
\hline Total phosphorus, $\%$ & 0.54 & 0.54 & 0.54 & 0.54 & 0.55 \\
\hline Methionine, \% & 0.37 & 0.37 & 0.37 & 0.37 & 0.37 \\
\hline Lysine, \% & 0.81 & 0.81 & 0.81 & 0.85 & 0.91 \\
\hline DE:CP & 147.88 & 147.88 & 147.72 & 147.17 & 147.03 \\
\hline
\end{tabular}

1- Supplied per Kg. of diet: 12000 IU Vit. A; 2200 IU D3; 10mg Vit. E; 2.0 mg Vit.K3; 1.0 mg Vit. B1; $4.0 \mathrm{mg}$ Vit. B2; $1.5 \mathrm{mg}$ Vit. B6; 0.0010mg Vit. B12; $6.7 \mathrm{mg}$ Vit. Pantothenic acid;6.67 mg Vit. B5; 1.07mg Biotin; $1.67 \mathrm{mg}$ Folic acid; 400 mg Choline chloride; 22.3 mg Zn;10 mg Mn; 25 mg Fe; 1.67 mg Cu; 0.25mg I; 0.033 mg Se and 133.4 mg Mg.l. 2-According to MOA (2001).

3-Calculated according to Cheeke (1987): DE (Kcal/g) $=4.36-0.0491$ (\%NDF). \%NDF = $28.924+0.657(\% \mathrm{CF}) . \% A D F=9.432+0.912(\% \mathrm{CF})$. Hemicellulose = \%NDF - \% ADF.

G1=group that fed the basal diet (control), G2 and G3= groups that fed the basal diet with artificial glutamic acid $(0.125$ and $0.25 \%), G 4$ and $G 5=$ groups that fed the basal diet in which tomato by-products substituted part of clover hay (natural glutamic acid, 0.125 and $0.25 \%)$.

Feed consumption was recorded weekly during the whole experimental period. Rabbits were weighed weekly from the beginning till the end of the experiment. Live body weight $(\mathrm{g})$, weight gain $(\mathrm{g})$, feed intake $(\mathrm{g})$, feed 
conversion (g feed/g gain), performance index\% (final live body weight $(\mathrm{kg}) /$ feed conversion*100 according to North, 1981), mortality rates (\%) were recorded. Some economic efficiency values were also calculated.

Table (2): Chemical analysis and amino acid contents (\%) of the tomato by-products

\begin{tabular}{|l|c|l|c|}
\hline \multicolumn{2}{|c|}{ Chemical analysis } & \multicolumn{2}{c|}{ Amino acid contents (\%) } \\
\hline Dry matter (DM, \%) & 93.95 & Aspartic acid & 3.14 \\
\hline Organic matter (OM, \%) & 89.45 & Threonine & 0.53 \\
\hline Crude protein (CP, \%) & 21.95 & Serine & 1.16 \\
\hline Crude fiber (CF, \%) & 38.00 & Glutamic acid & 2.49 \\
\hline Ether extract (EE, \%) & 8.50 & Proline & 0.02 \\
\hline Nitrogen free extract (NFE, \%) & 21.50 & Glycine & 2.46 \\
\hline Ash, \% & 4.50 & Alanine & 1.50 \\
\hline Calcium, \% & 0.77 & Valine & 0.90 \\
\hline Phosphorous, \% & 1.07 & Methionine & 0.31 \\
\hline DE (kcal / kg) & 1565 & Isoleucine & 1.00 \\
\hline Fiber fractions (\%) & & Leucine & 2.55 \\
\hline Neutral detergent fiber (NDF, \%) & 56.92 & Tyrosine & 0.55 \\
\hline Acid detergent fiber (ADF, \%) & 42.31 & Phenylalanine & 0.94 \\
\hline Acid detergent lignin (ADL, \%) & 9.18 & Histidine & 1.28 \\
\hline Hemicellulose, \% & 14.61 & Lysine & 2.24 \\
\hline Cellulose, \% & 33.13 & Ammonia & 4.00 \\
\hline \multicolumn{2}{|l|}{$\%$} & Arginine & 1.12 \\
\hline
\end{tabular}

${ }^{*}$ Calculated according to Cheeke (1987): $\mathrm{DE}(\mathrm{kcal} / \mathrm{g})=4.36-0.0491$ (\%NDF)

NDF $=$ cellulose + hemicellulose + lignin, Hemicellulose $(\%)=$ NDF - ADF, ADF= cellulose+ lignin

\section{Digestibility trials:}

At the end of the experimental period, three rabbits from each treatment were randomly selected to determine the digestion coefficients of nutrients and the feeding values of the experimental diets. Feed intake and fecal output were quantitatively collected for five consecutive days. A plastic net was placed beneath every cage to retain feces and at the same time allowing the passage of urine. Actual daily feed intake was recorded. Feces was daily sprayed with $2 \%$ boric acid for keeping up the feces ammonia, then oven dried at $60^{\circ} \mathrm{C}$ till constant weight, finely ground and stored for later chemical analysis. Diets and feces were analyzed according to A.O.A.C. (1996). Digestion coefficients of nutrients and nutritive values were calculated according to Abou-Raya (1967).

\section{Carcass measurements:}

At the end of the experimental, four rabbits from each group were slaughtered to study characteristics and cut-points of carcass. Rabbits were weighed just before slaughter as well as after complete bleeding. The following variables were measured on the carcass; pre-slaughter weight (PSW) (fasted weight); empty carcass weight with head (ECW, EC \%); dressed weight and percentage (DW, D \%) (total edible parts weight, which included empty carcass weight with head and edible giblets weight); edible giblets weight and percentage (EGW, EG \%) included liver, kidneys and heart weights; non edible parts weight and percentage (NEPW, NEP \%) (pre- 
slaughter weight - total edible parts weight). Carcass traits \% (skinning, head, liver, kidneys, heart and spleen) and carcass cuts (\%) means the weights of these parts divided by fasted weight * 100 .

The reference carcass was cut in the following points: cut-point 1 , section between the $7^{\text {th }}$ and $8^{\text {th }}$ thoracic vertebra; cut- point 2 , section between the last thoracic and the first lumbar vertebra, following the prolongation of the $12^{\text {th }}$ rib when cutting the thoracic wall; cut-point 3 , section between the $6^{\text {th }}$ and $7^{\text {th }}$ lumbar vertebra, cutting the abdominal wall transversally to the vertebral column; cut-point 4 , separation of fore legs including insertion and thoracic muscles according to Blasco et al. (1992). The cut-point 1, FL: fore-quarter (fore legs) including thoracic insertion muscles, cut-point 2, chest (C) (thoracic cage which included the first seven ribs, without the insertion muscles of the fore legs); cut-point 3, lion (L) (including abdominal wall and the ribs after the $7^{\text {th }}$ thoracic rib); cut-point 4 , Hind legs $(\mathrm{HL})$ (including the sacral bone and the lumbar vertebrae after the $6^{\text {th }}$ lumbar vertebra).

At the time of slaughter, blood samples were collected from four rabbits within each group. The blood samples were collected into dry clean centrifuge tubes containing few drops of heparin solution and centrifuged. Plasma was separated by centrifugation at 3000 r.p.m. for 20 minutes, stored in deep freezer at approximately $-20^{\circ} \mathrm{C} \pm 1$ until the time of analysis to estimate blood parameters. Enzyme activities included aspartate aminotransferase (AST) (U/I) and alanine aminotransferease (ALT) (U/I), they were determined using readymade kits (Diamond Diagnostics Company, Egypt). Urea $(\mathrm{mg} / \mathrm{dl})$ and creatinine $(\mathrm{mg} / \mathrm{dl})$ were determined calorimetrically using commercial kits (Diamond Diagnostics Company, Egypt) according to the methods described by manufactures.

\section{Economical efficiency:}

Economical efficiency was calculated as the ratio between income price of weight gain and cost of feed consumed at 5-16 weeks of age.

\section{Statistical analysis:}

All data were analyzed using the general linear models procedure of SAS (1999), data of percentages were subjected to arc-sin transformation to approximate normal distribution before being analyzed and means were separated using Duncan's multiple range tests (Duncan, 1955) for the comparison among means of the experimental diets when the main effects were significant. The model used was:

$Y_{i j}=\mu+T_{i}+e_{i j}$

Where: $\mu=$ overall mean of $Y_{i j}, T_{i}=$ Effect of treatment (1-5), eij $=$ Random error

\section{RESULTS AND DISCUSSION}

\section{Chemical analysis of tomato by-products:}

The proximate analysis and amino acid contents of tomato by-products are presented in Table (2) revealed that, tomato by-products had reasonable amount of protein and nitrogen free extract and high amount of EE, crude fiber particularly cellulose and phosphorous. Moderate amounts of ash and low amount of calcium and methionine were found. However, the present values 
were within the values reported by Khayyal (2006) and El-Medany et al. (2008). The dried tomato by-products were rich in most essential amino acids particularly, glutamic acid and lysine and were within the published range by Persia et al. (2003) and El-Medany et al. (2008). From the chemical analysis results, it is obvious that dried tomato by-products are rich in most nutrients and could be a good feedstuff with high nutritive value in terms of DE.

\section{Productive performance:}

In general, glutamic acid at the rate of $10 \%$ either from the artificial or the natural source had resulted in more weight gain than the $5 \%$ or the control one but without significant differences $(P>0.05)$. The artificial one was more pronounced than the natural one (Table 3). However, no significant differences $(P>0.05)$ in live body weight among groups at all ages, but it tended to be higher at 16 weeks of age in G3 by $2.9 \%, 4.4 \%, 11 \%$ and $2 \%$ than that in G1, G2, G4 and $\mathrm{G} 5$, respectively. It was also clear that the highest average body weight was achieved by G3\& G5 during the period 5 to 12 and 5 to 16 weeks of age. These results were in agreement with those of Peiretti et al. (2012), who reported that TP had no significant differences on weight gain.

Table (3): Productive performance as affected by glutamic acid in the experimental diets for growing APRI rabbits at different ages

\begin{tabular}{|c|c|c|c|c|c|c|}
\hline \multirow{2}{*}{ Item } & \multicolumn{5}{|c|}{ Experimental diets } & \multirow{2}{*}{ $\pm S E$} \\
\hline & G1 & G2 & G3 & G4 & G5 & \\
\hline \multicolumn{7}{|l|}{ Live body weight (g): } \\
\hline Weaning (5weeks) & 666.2 & 666.2 & 669.3 & 668.2 & 667.5 & \pm 22.9 \\
\hline 12 weeks & 1032.7 & 1045.2 & 1123.3 & 1017.4 & 1110.4 & \pm 50.9 \\
\hline 16 weeks & 1758.4 & 1731.7 & 1811.1 & 1611.0 & 1774.4 & \pm 92.3 \\
\hline \multicolumn{7}{|l|}{ Weight gain (g/kid): } \\
\hline 5-12 weeks & 366.5 & 379.1 & 453.9 & 349.3 & 442.9 & \pm 53.2 \\
\hline 12-16 weeks & 727.5 & 670.6 & 668.7 & 599.6 & 652.3 & \pm 46.9 \\
\hline 5-16 weeks & 1092.2 & 1065.5 & 1141.8 & 942.9 & 1106.9 & \pm 91.3 \\
\hline \multicolumn{7}{|l|}{ Feed intake(g/kid): } \\
\hline 5-12 weeks & $1783.0^{\mathrm{a}}$ & $1844.7^{a}$ & $1647.7^{\mathrm{b}}$ & $1408.1^{\mathrm{c}}$ & $1700.0^{\mathrm{b}}$ & \pm 28.9 \\
\hline 12-16 weeks & $3346.0^{\mathrm{a}}$ & $3131.1^{b}$ & $3081.2^{b}$ & $2823.4^{\mathrm{c}}$ & $2962.3^{c}$ & \pm 10.7 \\
\hline 5-16 weeks & $4691.0^{\mathrm{a}}$ & $4499.6^{a}$ & $4292.7^{b}$ & $3848.6^{\mathrm{c}}$ & $4263.3^{\mathrm{b}}$ & \pm 30.1 \\
\hline \multicolumn{7}{|c|}{ Feed conversion ratio ( $\mathrm{g}$ feed/g gain): } \\
\hline 5-12 weeks & $4.9^{\mathrm{b}}$ & $4.9^{b}$ & $3.6^{a}$ & $4.0^{\mathrm{a}}$ & $3.8^{a}$ & \pm 0.5 \\
\hline 12-16 weeks & $4.6^{b}$ & $4.7^{b}$ & $4.5^{\mathrm{a}}$ & $4.7^{a}$ & $4.5^{a}$ & \pm 0.2 \\
\hline 5-16 weeks & $4.3^{b}$ & $4.2^{\mathrm{b}}$ & $3.8^{a}$ & $4.1^{\mathrm{b}}$ & $3.9^{a}$ & \pm 0.3 \\
\hline \multicolumn{7}{|c|}{ Performance index ${ }^{1 \%}$ : } \\
\hline 5-12 weeks & $21.2^{\mathrm{b}}$ & $21.5^{\mathrm{b}}$ & $30.9^{a}$ & $25.3^{\mathrm{ab}}$ & $28.9^{a}$ & \\
\hline 12-16 weeks & 38.3 & 37.1 & 40.5 & 34.2 & 39.1 & \\
\hline 5-16 weeks & $40.9^{\mathrm{ab}}$ & $41.0^{\mathrm{b}}$ & $48.2^{\mathrm{a}}$ & $39.5^{\mathrm{b}}$ & $46.1^{\mathrm{ab}}$ & \\
\hline
\end{tabular}

a, b and c means in the same row with different superscripts are significantly (P $\leq 0.05)$ different.

${ }^{1}$ Calculated according to North (1981): Performance index \% = final live body weight $(\mathrm{Kg}) /$ feed conversion*100

G1=group that fed the basal diet (control), G2 and G3= groups that fed the basal diet with artificial glutamic acid $(0.125$ and $0.25 \%), \mathrm{G} 4$ and $\mathrm{G} 5=$ groups that fed the basal diet in which tomato by-products substituted part of clover hay (natural glutamic acid, 0.125 and $0.25 \%$ ). 
Feed intake was significantly affected by the diets. Lowest average feed intake from weaning to slaughter (5-16 weeks of age) was recorded for G4. These results may be due to the significantly higher $\mathrm{CP}$ and CF digestibility in G4 (Table 3). Also, it was lower for G5 and G3 than G2 and G1, which may be due to that glutamine stimulates absorption in treated tissues and $~ 95 \%$ of the energy provided by glutamine oxidation remains available to the enterocyte for basic cellular function and repair, leading to increased intestinal nutrient absorption (Abely et al., 2000).

Better feed conversion and performance index (\%) were recorded for $\mathrm{G} 3$ and G5 than in the other groups, in all ages. Rabbits of G3 and G5 showed better $(P<0.05)$ feed conversion than other groups for the whole period. This was probably due to the effect of the high fat content of the TP (Ahmed et al., 1994), which is in agreement with the results of Peiretti et al. (2012). Caro et al. (1993) reported that there was no significant differences in weight gain or feed conversion ratio among rabbits fed diets which contained 10,20 and $30 \%$ TP. The same authors found that the average daily feed intake by rabbits fed diets containing $30 \%$ TP was lower than those of rabbits fed diets with 0,10 or $20 \%$ TP. Similar results were found by Ahmed et al. (1994), who showed no significant differences in live weight and daily weight gain of rabbits fed rations contained levels of $0,10,20$ and $30 \%$ TP for seven weeks. The rabbits fed diet containing 30\% TP consumed lower amount of feed, while rabbits fed the control diet ( $0 \%$ TP) consumed higher amount of feed, which is probably due to the effect of the high fat content of the TP.

\section{Digestibility coefficients and nutritive values:}

The Chemical analysis (\%) of the experimental diets for growing APRI rabbits are presented in Table (4). It is shown that, determined values are close to the calculated values in Table (1).

Table (4): Chemical analysis (\%) of the experimental diets for growing APRI rabbits (as DM basis)

\begin{tabular}{|c|c|c|c|c|c|c|c|}
\hline \multirow{2}{*}{ Treatment } & \multicolumn{7}{|c|}{ Experimental diets } \\
\cline { 2 - 7 } & DM & OM & CP & CF & EE & NFE & Ash \\
\hline G1 & 87.90 & 93.10 & 17.85 & 13.80 & 3.20 & 58.25 & 6.90 \\
\hline G2 & 88.10 & 93.05 & 17.80 & 13.75 & 3.09 & 58.41 & 6.95 \\
\hline G3 & 88.00 & 93.08 & 17.80 & 13.70 & 3.10 & 58.48 & 6.92 \\
\hline G4 & 88.30 & 93.40 & 17.90 & 14.10 & 3.50 & 57.90 & 6.60 \\
\hline G5 & 88.50 & 93.80 & 17.85 & 14.60 & 3.95 & 57.40 & 6.20 \\
\hline
\end{tabular}

No significant differences for DM and OM digestibility coefficients. While higher $(P<0.05)$ digestion coefficients of $C P$ was noticed for groups 3,4 and 5 (Table 5). Groups 4 and 5 had higher digestion coefficients of CF compared to other groups. On the other hand, G2 and G3 had the lower $(P<0.05) E E$ and NFE digestibility coefficients. These results were reflected on TDN and DCP values, whereas groups 3,4 and 5 had the higher $(P<0.05)$ values. Improvement of $\mathrm{CP}, \mathrm{CF}$ digestion or DCP could be due to the difference in the content of digestible dietary fiber and/or changes in the origin of starch and protein (Blas et al., 1990). The improvement of crude fiber digestibility may be due to an improvement of cecal micro organisms, which have a major effect on fiber 
digestion in rabbits (Fernandez et al., 1994). Increasing TP in rabbits' ration could increase their extract level of the diet and the digestibility coefficients. Gippert et al. (1989) found that increasing TP in the diets improved feed utilization of nutrients in rabbits.

Table (5): Digestion coefficients of nutrients and nutritive values as affected by glutamic acid in the experimental diets for growing APRI rabbits

\begin{tabular}{|c|c|c|c|c|c|c|c|c|}
\hline \multirow{2}{*}{ Treatment } & \multicolumn{9}{|c|}{ Digestibility \% } & \multicolumn{3}{c|}{ Nutritive values \% $^{\mathbf{K}}$} \\
\cline { 2 - 9 } & DM & OM & CP & CF & EE & NFE & TDN & DCP \\
\hline G1 & 67.9 & 68.6 & $63.7^{\mathrm{b}}$ & $17.9^{\mathrm{b}}$ & $82.7^{\mathrm{a}}$ & $75.6^{\mathrm{ab}}$ & $60.9^{\mathrm{b}}$ & $11.1^{\mathrm{b}}$ \\
\hline G2 & 65.6 & 66.4 & $63.9^{\mathrm{b}}$ & $15.7^{\mathrm{b}}$ & $78.0^{\mathrm{b}}$ & $73.4^{\mathrm{b}}$ & $59.6^{\mathrm{b}}$ & $11.4^{\mathrm{b}}$ \\
\hline G3 & 65.7 & 66.1 & $66.1^{\mathrm{ab}}$ & $17.6^{\mathrm{b}}$ & $76.3^{\mathrm{b}}$ & $73.4^{\mathrm{b}}$ & $61.5^{\mathrm{ab}}$ & $13.1^{\mathrm{a}}$ \\
\hline G4 & 69.3 & 69.6 & $70.2^{\mathrm{a}}$ & $29.6^{\mathrm{a}}$ & $81.5^{\mathrm{a}}$ & $77.2^{\mathrm{a}}$ & $67.4^{\mathrm{a}}$ & $13.3^{\mathrm{a}}$ \\
\hline G5 & 69.2 & 69.7 & $70.2^{\mathrm{a}}$ & $28.3^{\mathrm{a}}$ & $82.2^{\mathrm{a}}$ & $78.3^{\mathrm{a}}$ & $68.7^{\mathrm{a}}$ & $13.8^{\mathrm{a}}$ \\
\hline
\end{tabular}

a, b and c means in the same column with different superscripts are significantly (P $\leq$ 0.05 ) different. ${ }^{\mathrm{K}}$ Calculated according to Abou-Raya (1967).

G1=group that fed the basal diet (control), G2 and G3= groups that fed the basal diet with artificial glutamic acid $(0.125$ and $0.25 \%)$, $\mathrm{G} 4$ and $\mathrm{G} 5=$ groups that fed the basal diet in which tomato by-products substituted part of clover hay (natural glutamic acid, 0.125 and $0.25 \%$ ).

Mortality rates:

The mortality rates recorded at 5,12 and 16 weeks of age are presented in Figure (1).

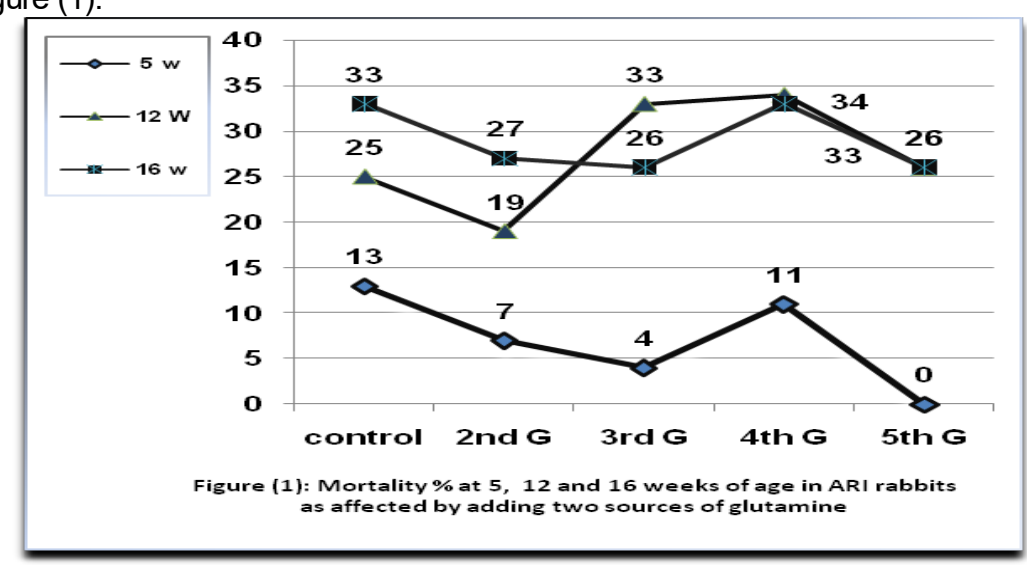

During the first growing period, the effect of dietary two source of glutamic acid showed that mortality rate was nil for G5, while, maximum mortality rate was recorded for G4 (34\%). Mortality rate was tended to be lower at week 16 for G3, G5 and G2 groups by $21,21,18,24,24$ and $21 \%$ than the other two groups (G1 and G4), respectively. This result is in agreement with those of Chamorro et al. (2010), who found that dietary supplementation with glutamine decreased post weaned rabbit mortality. Also, El-Hassan (1999) investigated the possibility of replacing the tomato pomace at 2.5 and $10 \%$ levels of, whereas a decrease in 
mortality was happened. This finding is also supported by the results of Ahmed et al. (1994) who reported that the lowest mortality rate was found with diet contained $10 \%$ TP. Abd El-Razik (1996) and El-Medany (2008) found no mortality in groups of rabbits fed diets contained dried tomato pulp. The enhanced sanitary status observed in rabbits fed the glutamine supplemented diets may be due to the positive effect of this amino acid on mucosal barrier mechanisms or/and throughout changes on the intestinal macrobiotic, Also it helps to maintain mechanisms of epithelial cell proliferation and fuelling gut metabolism (Baylos et al., 2008).

\section{Carcass traits:}

Commercial empty carcass weight was insignificantly affected by treatments (Table 6). Empty carcass (\%) was significantly heavier for G3 and G5. Significantly higher dressing (\%) was found for G5, followed by G3 than other groups. This may be due to the effect of the fat content of TP (Peiretti et al., 2012). These results indicated that using TP at a rate of $10 \%$ improved carcass traits which agreed with; Ibrahim (2005). Edible giblets (\%) were not significantly different among tested diets. This result was in agreement with those of Elazab et al. (2011) who concluded that TP had no adverse effect on edible giblets (\%).

Table (6): Carcass traits and percentage as affected by glutamic acid in the experimental diets for growing APRI rabbits

\begin{tabular}{|c|c|c|c|c|c|c|c|c|c|}
\hline Treatment & $\begin{array}{c}\text { Pre- } \\
\text { slaughter } \\
\text { weight } \\
\text { (fasted) }\end{array}$ & \multicolumn{2}{|c|}{ Empty carcass } & \multicolumn{2}{|c|}{$\begin{array}{c}\text { Dressing } \\
\text { (total edible } \\
\text { parts) }\end{array}$} & \multicolumn{2}{|c|}{ Edible giblets } & \multicolumn{2}{|c|}{$\begin{array}{c}\text { Non-edible } \\
\text { parts }\end{array}$} \\
\hline & $(\mathrm{g})$ & $(\mathrm{g})$ & $\%$ & $(\mathrm{~g})$ & $\%$ & $(\mathrm{~g})$ & $\%$ & $(\mathrm{~g})$ & $\%$ \\
\hline G1 & 1693.3 & 731.3 & $43.2^{\mathrm{b}}$ & 801.6 & $47.3^{\mathrm{b}}$ & $70.3^{\mathrm{b}}$ & 4.2 & 891.7 & $52.7^{\mathrm{a}}$ \\
\hline G2 & 1616.7 & 655.5 & $40.5^{\mathrm{b}}$ & 722.8 & $44.7^{\mathrm{b}}$ & $67.3^{\mathrm{bc}}$ & 4.2 & 893.9 & $55.3^{\mathrm{a}}$ \\
\hline G3 & 1852.0 & 892.4 & $48.2^{\mathrm{a}}$ & 980.1 & $52.9^{\mathrm{a}}$ & $87.7^{\mathrm{a}}$ & 4.7 & 871.9 & $47.1^{\mathrm{b}}$ \\
\hline G4 & 1587.3 & 690.8 & $43.5^{\mathrm{b}}$ & 757.1 & $47.7^{\mathrm{b}}$ & $66.3^{\mathrm{bc}}$ & 4.2 & 830.2 & $52.3^{\mathrm{a}}$ \\
\hline G5 & 1655.0 & 797.4 & $48.2^{\mathrm{a}}$ & 876.7 & $53.0^{\mathrm{a}}$ & $79.3^{\mathrm{a}}$ & 4.8 & 778.3 & $47.0^{\mathrm{b}}$ \\
\hline ISE & \pm 80.7 & \pm 50.6 & & \pm 53.7 & & \pm 4.9 & & \pm 51.7 & \\
\hline
\end{tabular}

a, $b$ and $c$ means in the same column with different superscripts are significantly (P $\leq 0$. 05) different.

Total edible parts wt. $=$ Empty carcass wt. $($ with head $)+$ edible giblets wt.

Edible giblets wt. = Liver+ Kidneys wt. + Heart wt.

Total edible parts $\%=$ Total edible parts wt $/$ Fasted wt. *100

G1=group that fed the basal diet (control), G2 and G3= groups that fed the basal diet with artificial glutamic acid $(0.125$ and $0.25 \%), \mathrm{G} 4$ and $\mathrm{G} 5=$ groups that fed the basal diet in which tomato by-products substituted part of clover hay (natural glutamic acid, 0.125 and $0.25 \%$ ).

There were significant higher skinning and head for G5 than other treatments (Table 7). Carcass cuts (\%) tended to be higher for G5, followed by G3, which had better carcass cuts. These results are in agreement with those reported by Ibrahim (2005) and Sayed and Abdel-Azeem (2009), who reported that the optimum level of TP was $13.2 \%$ in rabbit's diet to improve carcass cuts.

Concerning commercial carcass cut (\%), G5 and G3 had mild higher values than the other groups. The lion portion differed significantly among groups, but was higher in G5. This agrees with the results reported by 
Devasena et al. (2007) who reported that lion portion was higher for rabbits fed TP at ratio of 10 and $15 \%$ than the control group.

Table (7): Carcass traits, cuts and percentage as affected by glutamic acid in the experimental diets for growing APRI rabbits

\begin{tabular}{|c|c|c|c|c|c|c|c|c|c|c|}
\hline \multirow[b]{2}{*}{ Treatment } & \multicolumn{6}{|c|}{ Carcass traits (\%) } & \multicolumn{4}{|c|}{ Carcass cuts (\%) } \\
\hline & Skinning & Head & Liver & Kidneys & Heart & Spleen & $\begin{array}{c}\text { Fore- } \\
\text { quarter }^{1}\end{array}$ & Chest $^{1}$ & Loin $^{1}$ & $\begin{array}{c}\text { Hind- } \\
\text { quarter }^{1}\end{array}$ \\
\hline G1 & $16.3^{\mathrm{ab}}$ & $6.9^{\mathrm{ab}}$ & 3.26 & $0.66^{a b}$ & 0.27 & 0.06 & $4.16^{\mathrm{ab}}$ & 9.09 & $11.70^{\mathrm{ab}}$ & $15.01^{b}$ \\
\hline G2 & $13.9^{b}$ & $6.9^{a b}$ & 3.29 & $0.61^{b}$ & 0.27 & 0.05 & $3.98^{b}$ & 8.55 & $10.01^{\mathrm{b}}$ & $15.66^{\mathrm{ab}}$ \\
\hline G3 & $16.3^{\mathrm{ab}}$ & $6.1^{\mathrm{ab}}$ & 3.63 & $0.82^{a}$ & 0.30 & 0.04 & $4.32^{a}$ & 9.92 & $12.07^{a}$ & $18.78^{a}$ \\
\hline G4 & $14.8^{b}$ & $7.5^{\mathrm{a}}$ & 3.38 & $0.59^{b}$ & 0.23 & 0.06 & $3.89^{b}$ & 8.82 & $10.88^{\mathrm{ab}}$ & $15.78^{\mathrm{ab}}$ \\
\hline G5 & $17.8^{\mathrm{a}}$ & $7.7^{\mathrm{a}}$ & 3.75 & $0.74^{\mathrm{ab}}$ & 0.27 & 0.06 & $4.41^{a}$ & 10.02 & $12.26^{\mathrm{a}}$ & $19.09^{a}$ \\
\hline
\end{tabular}

$a$ and $b$ means in the same column with different superscripts are significantly $(P \leq 0.05)$ different.

${ }^{1}$ On relative to pre-slaughter weight (fasted weight). G1=group that fed the basal diet (control), G2 and G3= groups that fed the basal diet with artificial glutamic acid (0.125 and $0.25 \%$ ), G4 and G5= groups that fed the basal diet in which tomato by-products substituted part of clover hay (natural glutamic acid, 0.125 and $0.25 \%$ ).

\section{Blood parameters:}

No significant differences in liver function (AST and ALT, U/I) were detected among groups (Table 8). Michael (2000) suggested that glutamine could help in improving glutathione production in the liver. Glutathione is the main antioxidant that the body makes and it is critically important for detoxifying activities done by the liver (Jian-Chun et al., 1999). Adding TP to growing rabbits diets at $10 \%$ level decreased liver AST and ALT enzymes' activities compared to the control one, this agreed with the results of Rho and Kim (2006) and Elazab et al. (2011) who concluded that there were no adverse effect on AST and ALT enzyme activity when rabbits were fed diets containing different levels from tomato pomace (10, 15 and $20 \%$ ) compared to the control group

Table (8): Liver and kidney functions (Means \pm SE) as affected by glutamic acid in the experimental diets for growing APRI rabbits

\begin{tabular}{|c|c|c|c|c|c|c|}
\hline \multirow{2}{*}{ Item } & \multicolumn{5}{|c|}{ Experimental diets } & \multirow{2}{*}{ $\pm S E$} \\
\hline & G1 & G2 & G3 & G4 & G5 & \\
\hline AST (U/I) & 88.23 & 38.89 & 45.33 & 92.44 & 79.33 & \pm 21.32 \\
\hline ALT (U/I) & 68.76 & 26.44 & 30.31 & 72.32 & 36.91 & \pm 19.01 \\
\hline Urea (mg/dl) & $49.80^{a}$ & $41.49^{\mathrm{ab}}$ & $27.15^{\mathrm{c}}$ & $36.05^{\mathrm{b}}$ & $36.89^{b}$ & \pm 8.11 \\
\hline Creatinine (mg/dl) & $2.31^{\mathrm{a}}$ & $1.88^{\mathrm{b}}$ & $1.20^{\mathrm{b}}$ & $1.73^{b}$ & $2.10^{b}$ & \pm 0.32 \\
\hline
\end{tabular}

a, $b$ and $c$ means in the same row with different superscripts are significantly $(P \leq 0.05)$ different.

G1=group that fed the basal diet (control), G2 and G3= groups that fed the basal diet with artificial glutamic acid (0.125 and $0.25 \%)$, $\mathrm{G} 4$ and $\mathrm{G} 5=$ groups that fed the basal diet in which tomato by-products substituted part of clover hay (natural glutamic acid, 0.125 and $0.25 \%$ ).

Urea $(\mathrm{mg} / \mathrm{dl})$ and creatinine $(\mathrm{mg} / \mathrm{dl})$ concentrations in blood plasma of rabbits fed the experimental diet were significantly affected by the treatments. 
Rabbits of G3 recorded the lowest values of plasma urea and creatinine (Table 8). This may indicated that the kidney function seemed to be not affected by feeding TP (Ibrahim, 2005), due to the reduction in acid buildup, (Michael, 2009).

\section{Economical efficiency:}

Rabbits of G4 and G5 were found to have better economic efficiency (Table 9). The TP can be successfully used as a suitable ingredient in pelleted complete feed for weaning rabbits and it could be more economic than glutamic acid under Egyptian condition. The present results revealed also, that TP at the rate of $10 \%$ could be better as the feed cost/ kg gain (Abd El-Razik, 1996 and Khayyal, 2006).

Table (9): Economical efficiency as affected by glutamic acid in the experimental diets for growing APRI rabbits

\begin{tabular}{|l|c|c|c|c|c|}
\hline \multirow{2}{*}{ Item } & \multicolumn{5}{c|}{ Experimental diets } \\
\cline { 2 - 6 } & G1 & G2 & G3 & G4 & G5 \\
\hline Price / kg diet (L.E) & 2.08 & 2.21 & 2.33 & 2.00 & 1.92 \\
\hline Total feed intake/rabbit (gm) & 4691.0 & 4499.6 & 4292.7 & 3848.6 & 4263.3 \\
\hline Total feed cost/rabbit (L.E) & 9.76 & 9.94 & 10.00 & 7.70 & 8.19 \\
\hline Total weight gain/rabbit (gm) & 1092.24 & 1065.48 & 1141.79 & 942.87 & 1106.90 \\
\hline Feed cost / kg gain (L.E) & 8.93 & 9.33 & 8.76 & 8.16 & 7.40 \\
\hline Total revenue/rabbit (L.E) & 21.84 & 21.31 & 22.84 & 18.86 & 22.14 \\
\hline Net revenue/rabbit (L.E) & 12.09 & 11.37 & 12.83 & 11.16 & 13.95 \\
\hline $\begin{array}{l}\text { Economical efficiency } \\
\text { ( E.EF) }\end{array}$ & 1.24 & 1.14 & 1.28 & 1.45 & 1.70 \\
\hline Relative E. EF\% & 100 & 92 & 104 & 117 & 138 \\
\hline
\end{tabular}

Based on prices of the Egyptian market during the experimental period (2012).

The price of one ton of clover hay $(12 \% \mathrm{CP})$, yellow corn, soybean meal $(44 \% \mathrm{CP})$, wheat bran, methionine, molasses, vitamins\& minerals mix., salt, lime stone and Dicalcum phosphate were 1500, 2000, 3000, 1800, 44000, 1500, 75000,250, 500 and 1200 LE, respectively. The prices of one ton tomato by-products, glutamic acid and body weight on selling were 100,100000 and 20 LE, respectively. Initial price of rabbit 20 LE. Net revenue $I$ rabbit $($ LE) $=$ (Total revenue $/$ rabbit (LE)) - (Total feed cost $/$ rabbit (LE)) . Economical efficiency $=($ Net revenue/rabbit (LE)) $/$ (Total feed cost/rabbit (LE). Feed cost $/ \mathrm{kg}$ gain $=$ Total feed cost/rabbit (LE) *1000 $/$ Total weight gain/rabbit (gm) .

G1=group that fed the basal diet (control), G2 and G3= groups that fed the basal diet with artificial glutamic acid (0.125 and $0.25 \%), \mathrm{G} 4$ and $\mathrm{G} 5=$ groups that fed the basal diet in which tomato by-products substituted part of clover hay (natural glutamic acid, 0.125 and $0.25 \%$ ).

\section{Conclusions}

In conclusion natural dried tomato by-products (TP) as a source of glutamic acid could be used in feeding of growing rabbits up to $10 \%$ of the diet with no adverse effect on productive performance, carcass traits, physiological function and economical efficiency. 


\section{REFERENCES}

Abd El-Razik, W.A. (1996). Effect of substitution of tomato pomace for corn in growing rabbit diets on growth performance and carcass traits. Egypt J. Rabbit Sci., 6: 79-86.

Abely, M., P. Dallet, M. Biosset and J.F. Desjeux (2000). Effect of cholera toxin on glutamine metabolism and transport in rabbit ileum. American J. Physiology Gastrointestinal and Liver Physiology, 278(5): 789-796.

Abou-Raya, A.K. (1967). Animal and Poultry Nutrition. Dar-El-Maarif, Cairo, (Arabic Textbook).

Agriculture Ministry Decree (1996). The Standard Properties for Ingredients, Feed Additives and Feed Manufactured for Animal and Poultry. El- Wakaee.

Ahmed, S.S., K.M. El-Gendy, H. Ibrahim, A.A. Rashwan and M.I. Tawfeek (1994). Growth performance, digestibility, carcass traits and some physiological aspects of growing rabbits fed tomato pomace as a substitution for alfalfa meal. Egyptian J. Rabbit Sci., 4: 1-13.

A.O.A.C. (1996). Official Methods of Analysis, Association of Official Analytical Chemists. 16th edition, Washington, USA.

Baylos, M., D. Menoyo, S. Chamorro, A. Sainz, N. Nicodemus, J.C. de Blas and R. Carabaño (2008). Effect of dietary level and source of glutamine on intestinal health in the postweaning period. 9th World Rabbit Congress -June 10-13, 2008, Verona - Italy, pp. 529-533.

Blanospino, E., A.S.A.M. Moura, F.S. Wechsler, S. Fernandes and R.O. Roca (2004). Carcass and meat quality of straight breed and crossbred rabbits. Proceedings, 8th World Rabbit Congress, September 7-10, Puebla, Mexico.

Blas, E., J.C. Fandos, C. Cervera, T. Gidenne and J.M. Perez (1990). Effect of the nature and level of starch on digestibility of the diet in rabbits during the growth. In: Proc. of the $5^{\text {th }} \mathrm{J}$. Research of Cunicole, 12-13 December 1990, ITAVI, Paris. Vol. 2: 501-509.

Blasco, A., J. Ouhayoun and G. Masoero (1992). Status of rabbit meat and carcass. Criteria and terminology. Options Méditerranéennes, Série Séminaires, No (17): 105-120.

Caro, T.W., B.H. Manterola and A.D. Cerda (1993). Studies of the use of agroindustrial byproducts in animal feeding. Avances en Produccion Animal, 18(1/2): 91-97.

Chamorro, S., R. Carabaño, G. Grant, J. Garcia, J.C. De Blas (2007a). Efecto de la adición de glutamina y arginina sobre la mortalidad y barrera intestinal en gazapos. In: Proc. II Congreso Ibérico De Cunicultura, 2007 June, Vila-Real, Portugal, 91-94. (Cieted by Baylos et al., 2008).

Chamorro, S., R. Carabaño, I. Badiola, J. García, J.C. De Blas (2007b). Effet d'une supplémentation alimentaire en glutamine et en arginine sur, la croissance, quelques paramètres de la flore iléale et caecale et la santé intestinale chez le lapereau, sevré précocement et atteint par le syndrome de l'EEL. In: Proc. 12èmes Journées De La Recherche Cunicole, Le Mans,France. (Cited by Baylos et al., 2008).

Chamorro, S., C. de Blas, G. Grant, I. Badiola, D. Menoyo and R. Carabaño (2010). Effect of dietary supplementation with glutamine and a combination of glutamine-arginine on intestinal health in twenty-five-day-old weaned rabbits. J. Animal Sci., 88 (1):170-180. 
Cheeke, P.R. (1987). Rabbit Feeding and Nutrition. Academic Press. Orlando, Florida, U. S.A.

Christy, C.C. (2010). Difference between L-Glutamic acid and L-Glutamine. www.livestrong.com article, 292730, Oct 31/\#ixzz26zYaN6iX.

Dalle Zotte A. (2002). Perception of rabbit meat quality and major factors influencing rabbit carcass and meat quality. Livestock Production Sci., 75(1): 11-32.

Devasena, B., B. Punyakumari, J. V. Ramana, D.S. Kumar and J. Ramaprasad (2007). Utilization of tomato ( $L$. esclentum) pomace in broiler rabbit diets. Indian J. Small Ruminant, 13: 65-69.

Duncan, D.B. (1955). Multiple range and multiple F-Test. Biometrics, 1:42.

Elazab, M.A., S.M. Zahran, M.H. Ahmed, A.E. Elkomi (2011). Productive performance of growing rabbits fed diet containing different levels of tomato pomace. Benha Veterinary Medical J., 22 (2):44-55.

El-Hassan, M. A. EC. (1999). Effect of some agricultural industrial byproducts on the performance of broiler chicks. Ph.D. Thesis, Fac. Agric., Zagazig Univ., Egypt.

El-Medany, N.M., N.A. Hashem and F. Abdel-Azeem (2008). Effect of using dried tomato pomace in growing rabbit diet. Egyptian J. Nutrition feeds, 11(1): 39-53.

FAO (2011). FAOSTAT. Food and Agricultural Organization of the United Nations.

Fernandez, C., A. Cobos and M. J. Fraga (1994). Effect of fat inclusion on diet digestibility in growing rabbits. J. Animal Sci., 72, 1508-1518.

Fischer da Silva, A.V. (2001). Efeitos da restrição alimentar precoce e da glutamina no desenvolvimento e na mucosa intestinal em frangos. Tese de Doutorado, Universidade Estadual Paulista/Faculdade de Ciências Agrárias e Veterinárias de Jaboticabal, 77f. (Cited by Fischer da Silva et al., 2007).

Fischer da Silva, A.V., A. Maiorka, S.A. Borges, E. Santin, I.C. Boleli and M. Macari (2007). Surface area of the tip of the enterocytes in small intestine mucosa of broilers submitted to early feed restriction and supplemented with glutamine. Int. J. Poultry Sci., 6 (1): 31-35.

Gippert, T., S. Lacza and J. Hullar (1989). Utilization of agricultural by-products in the nutrition of rabbit. Proceeding of 4 th World Rabbit Congress. Budapest, 1: 163172.

Goering, H.K. and P.T. Van Soest (1970). Forage Fiber Analysis (apparatus, reagent, procedures and some applications), ARS, US. Dept. Agri. Handbook, Washington, DC. 20402.

Ibrahim, W.A.E. (2005). Inclusion of some wastes in rabbit diets. M.D. Thesis, Fac. of Agric., Al-Azhar Univ., Egypt.

Jian-Chun, Y.U. Jiang Zhu-Ming and L.I. De-Min (1999). Glutamine: a precursor of glutathione and its effect on liver. World Journal of Gastroenterology, 5(2):143146.

Kharchenko, G. (2012). Supplemental amino acids: gamma-aminobutyric acid (GABA), glutamic acid, glutamine and glutathione, glycine, histidine, homocysteine. American, Medicineneeds.com/potassium-wasting-diuretics.

Khayyal, Amany A. (2006). Utilization of some agricultural by-products in feeding rabbits. Ph.D. Thesis, Fac. of Agric., Cairo Univ., Egypt.

Karadas, F., P. Surai, E. Grammenidis, N.H. Sparks and T. Acamovic (2006). Supplementation of the maternal diet with tomato powder and marigold extract: effects on the antioxidant system of the developing quail. Br. Poult. Sci. 47: 200-208. 
King, A.J. and G. Zeidler (2004). Tomato pomace may be a good source of vitamin $E$ in broiler diets. Calif. Agric., 58: 59-62.

Michael, M. (2000). Glutamine and N-Acetyl Cysteine. www.mediblics/HCV2.htm.

Michael, M. (2009). L-glutamine. National. Handbook and kidney function of Nutrition. Nutrition Center, A ebsite from Blackpool Nutrition Centre, pp 336.

Mirzaei-Aghsaghali, A., N. Maheri-Sis, A. Mirza-Aghazadeh, A.R. Safaei and A.A. Aghajanzadeh-Golshani (2008). Nutritional value of alfalfa varieties for ruminants with emphasis on different measuring methods: A Review. Research J. Biol. Sci., 3: 1227-1241.

MOA (2001). Feed Composition Tables for Animal and Poultry Feedstuff Used in Egypt. Technical Bulletin No.1, Central Lab for Feed and Food, Ministry of Agriculture, Egypt.

Newsholme, Ph., J. Procopio, M.M. Lima, T.C. Pithon-Curi and R. Curi (2003). Glutamine and glutamate: Their central role in cell metabolism and function. Cell Biochemistry Function, 21: 1-9.

North, M.O. (1981). Commercial Chicken Production Manual. $3^{\text {rd }}$ Ed, Avi., Publishing Company. I.N.C. Westport Connecticut, USA.

Peiretti, P.G., F. Gai, L. Rotolo and L. Gasco (2012). Effects of diets with increasing levels of dried tomato pomace on the performances and apparent digestibility of growing rabbits. Asian J. Animal Veterinary Advances, 7: 521-527.

Pelicia, V.C., J.R. Sartori, A.C. Stradiotti, P.C. Araujo, M.K. Maruno, G.V. Polycarpo and A.C. Pezzato (2011). Glutamine, glutamic acid and phytogenic products as alternative additives in broiler feeds. XXII Latain American Poultry Congress 2011.

Persia, M.E, C.M. Parsons, M. Schang and J. Azcona (2003). Nutritional evaluation of dried tomato seeds. Poultry Sci., 82: 141-146.

Pierzynowski, S.G. and A. Sjodin (1998). Perspectives of glutamine and its derivatives as feed additives for farm animals. J. Animal Feed Sci., 7: 79-91.

Piles, M., A. Blasco and M. Pla (2000). The effect of selection for growth rate on carcass composition and meat characteristic of rabbits. Meat Sci., 54, 347-355.

Rho, K.A. and M.K. Kim (2006). Effects of different grape formulations on antioxidative capacity, lipid peroxidation and oxidative DNA damage in aged rats. J. Nutrition Sci Vitaminol (Tokyo), 52(1):33-46.

SAS Institute, Inc. (1999). SAS User's Guide: Statistics, SAS Institute Inc, Cary, N.C.

Sayed, A.N. and A.M. Abdel-Azeem (2009). Evaluation of dried tomato pomace as feedstuff in the diets of growing rabbits. International J. Agri. Veterinary Medical Sci., Vol. 3:13-18.

Sindhu, A.A., M.A. Khan, Mahr-Un-Nisa, M. Sarwar (2002). Agro-industrial byproducts as a potential source of livestock feed. Int. J. Agric. Biol., 4(2): 307310.

Ventura, M.R., M.C. Pieltin and J.I.R. Castanon (2009). Evaluation of tomato crop byproducts as feed for goats. Anim. Feed Sci. Technol., 154(3-4): 271-275. 
Shabaan, Hoda A. et al.

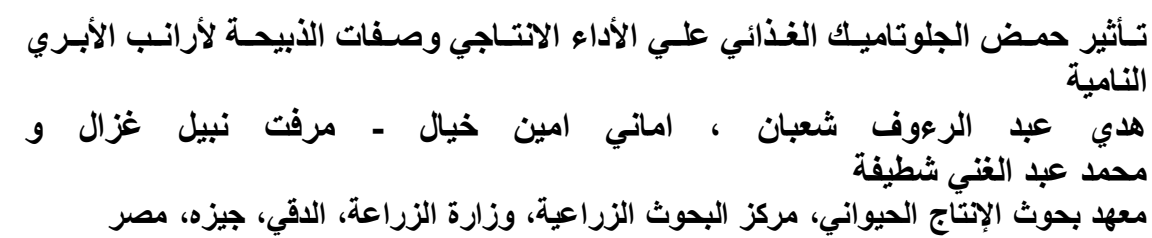

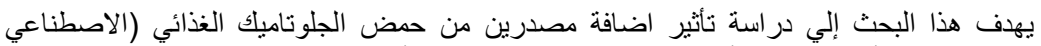

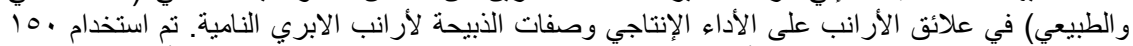

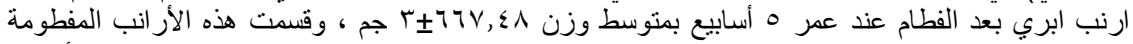

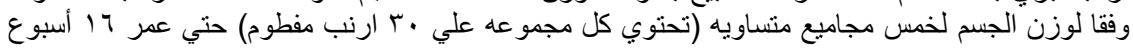

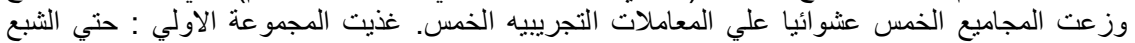

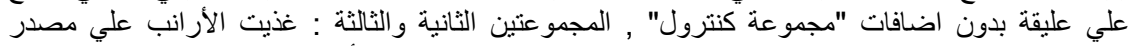

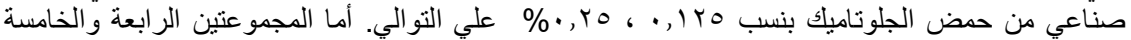

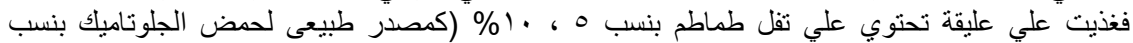

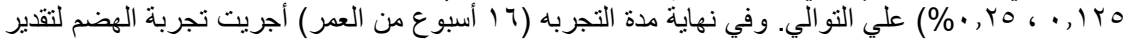

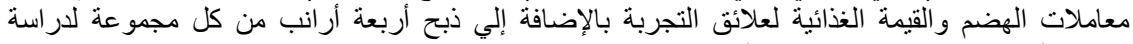

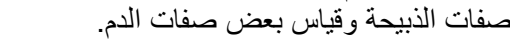

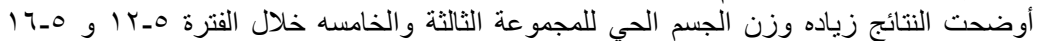

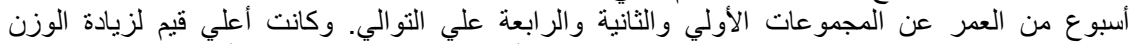

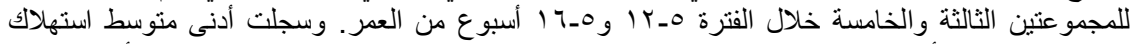

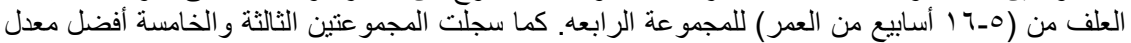

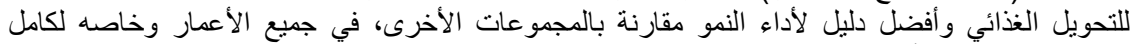

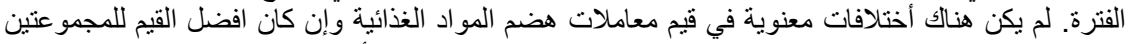

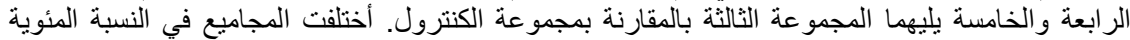

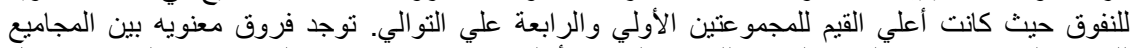

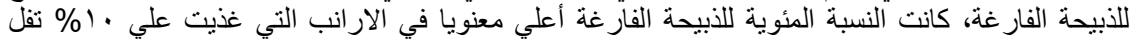

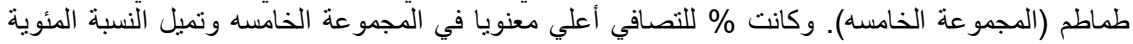

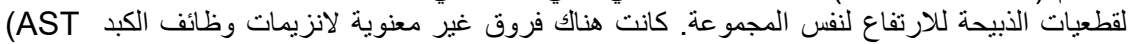
and ALT)

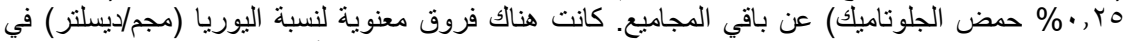

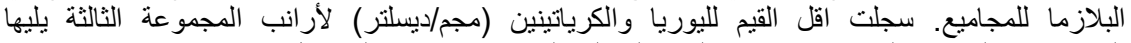

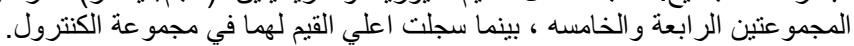

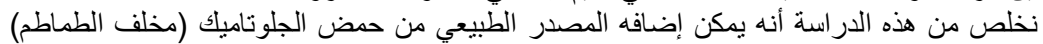

لعلائق الأرانب حتي مستوي • 1\% للحصول علي أفضل عائد إقتصادي و صنات صنات ذبيحة جيده بدون أي تأثير ات ضاره.

كلية الزر اعه - جامعة المنصوره

مركز البحوث الزراعيه

\author{
قام بتحكيم البحث

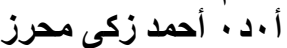

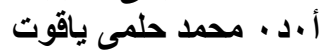

